\title{
DIREITO PÚBLICO NA ORIGEM DO BRASIL: ORGANIZAÇÃO ADMINISTRATIVA, TRIBUTÁRIA, GOVERNAMENTAL E JUDICIÁRIA DAS CAPITANIAS HEREDITÁRIAS
}

\section{Wagner Feloniuk*}

RESUMO: Trabalho de análise jurídica de uma das fases mais antigas do ordenamento jurídico brasileiro, a da implantação das Capitanias Hereditárias, em 1530. É dada ênfase na estruturação das capitanias e nos assuntos que atualmente estariam incluídos no Direito Público. Realiza-se uma descrição histórica do período e após, analisa-se fonte primária para descrever as normas das capitanias, com seções específicas para a organização administrativa, tributária, governamental e judiciária. Os capitães eram dotados de importante autonomia, diferentemente do que ocorreria a partir da implementação do Governos-Gerais.

PALAVRAS-CHAVE: História do Direito. Direito Público. Capitanias Hereditárias. Colônia. Direito Administrativo. Direito Tributário.

\section{PUBLIC LAW IN THE ORIGIN OF BRAZIL: ADMINISTRATIVE, TAX, GOVERNAMENTAL AND JUDICIAL ORGANIZATION OF THE HEREDITARY CAPITANIES}

\begin{abstract}
This paper analysis one of the oldest phases of the Brazilian law, the implantation of the hereditary capitanies in 1530. It is given emphasis on the capitanies structure and in subjects that would be currently included in Public Law. It is done a historical description of the period and then a primary source is analyzed to describe the rules of the capitanies, with specific sections for administrative, tax, governmental and judicial organization. The captains were endowed with a large degree of autonomy, contrary to what happen after the General-Government implamentantion.
\end{abstract}

KEYWORDS: Legal History. Public Law. Hereditary Capitanies. Colony. Administrative Law. Taw Law.

\section{INTRODUÇÃO}

\footnotetext{
* Professor Adjunto de Direito no Curso de Relações Internacionais da Universidade Federal do Rio Grande FURG (2019-atual). Doutorado em Direito na Universidade Federal do Rio Grande do Sul (2016) e, pela mesma instituição, Mestrado Acadêmico (2012), Especialização em Direito do Estado (2011) e Graduação em Ciências Jurídicas e Sociais (2010). Editor-Executivo da Revista do Instituto Histórico e Geográfico do Rio Grande do Sul. Pesquisador dos Grupos de Pesquisa CAPES: A formação de ordens normativas no plano internacional (FURG), A metodologia jurídica na Pós-Modernidade (UFRGS) e Direito e Filosofia (UFRGS). Membro da Associação Nacional de História, Conselho Nacional de Pesquisa e Pós-Graduação em Direito, Associação Brasileira de Editores Científicos, Instituto Histórico e Geográfico do Rio Grande do Sul e do Grupo História e Direito da ANPUH/RS.
} 
Dentre as normas mais antigas a serem trazidas ao Brasil após a chegada dos portugueses, aquelas destinadas à primeira organização das capitanias hereditárias são um destaque, sendo uma manifestação complexa e detalhada sobre o projeto de povoamento das vastas terras americanas. O presente trabalho busca analisar essas normas sob um viés jurídico formal, mostrando o funcionamento e principais características daquele ordenamento jurídico em sua estrutura normativa.

O objetivo é criar um quadro sobre as normas que inicialmente foram implantadas no Brasil, fazendo a análise social possível de sua implantação. Elas tiveram reduzidíssima efetividade, pois o sistema seria abandonado por um mais centralizador menos de duas décadas depois, após as grandes dificuldades enfrentadas para dar funcionamento básico às capitanias. Tais normas eram detalhadas, minuciosas e dependiam de uma burocracia estatal e de uma sociedade que inexistiam no Brasil, o que as tornava inefetivas e destoantes do contexto existente. A utilidade do trabalho, ao invés de estudar seu patamar de efetivação, é verificar a organização que Portugal pretendeu dar ao Brasil no seu nascimento. Demonstrar que já nelas aparecem os traços portugueses de normas pensadas para dar liberdade de adaptação à cultura e formação de estruturas e instituições locais que reconheciam a coroa sem ter nela um centro direto e intenso de direção, como narram os estudos de Hespanha.

Estruturalmente, o trabalho apresentará um embasamento histórico inicial, dará um panorama das capitanias hereditárias e, então, entrará em particular nas funções de administração, governo e judicial planejadas para o Brasil. Há também uma seção sobre a função legislativa, porém será visto que essa função não foi delegada pelo rei.

A principal fonte utilizada para o trabalho são as "Specimen das Cartas de Doações e Foraes das Capitanias", retiradas da obra História do Direito Nacional de José Izidoro Martins Junior, de 1895. Além delas, utiliza-se doutrina sobre o Direito Público brasileiro, História do Direito e História do Brasil, contextualizando a análise normativa. É realizada uma análise dedutiva voltada a criar um sistema que facilite a compreensão das normas que, em suma, formavam a organização brasileira daquele período.

O trabalho apresenta delimitação temporal bastante específica, inicia implantação das capitanias hereditárias até a implantação do Governo-Geral em 1548. A delimitação em um período curto permite uma maior acuidade e detalhamento, pois se tratará apenas de um conjunto de normas, sem a necessidade de se estabelecer generalizações. 


\section{PRIMÓRDIOS DA ORGANIZAÇÃO GOVERNAMENTAL BRASILEIRA E PRIMEIRAS ELEIÇÕES}

A Europa era um continente de oitenta milhões de habitantes quando o Brasil foi oficialmente registrado nos mapas europeus (RODRIGUES, 2014, p. 2), seis anos após o Tratado de Tordesilhas. Uma grande potência da época era Portugal, possuidor de uma frota de navios tecnologicamente avançados - os únicos capazes de levar artilharia pesada a bordo (CALMON, 2002, p. 34), e possuidores da tecnologia de navegação astronômica, o que inaugurou a possibilidade de afastamento da costa por longos períodos de tempo (DOMINGUES, 2007, p. 8-10). Uma parte relevante da riqueza do país vinha das Índias. A venda das especiarias da Europa sem passar pelas dificuldades da rota por terra gerava lucros grandes. Apesar dos riscos e das perdas de navios, a atividade era central para o país. Para garantir a exploração dessas riquezas orientais, Portugal instalou diversas feitorias comerciais ao longo da costa africana e da asiática (SIMONSEN, p. 99-100).

O Brasil, Terra de Santa Cruz, não justificava um investimento tão alto para sua exploração nesse cenário imediatamente posterior ao descobrimento, pois não tinha os mesmos atrativos das regiões da Ásia, prontas para comerciar mercadorias. Não havia riquezas para serem trazidas facilmente, nem escravos para serem traficados ou metais preciosos. A expansão portuguesa, sobretudo o crescimento comercial e o engrandecimento do Império, não foram feitos por uma política ordenada de expansão até meados do século XVIII (HESPANHA, 2005, p. 5) e o Brasil não teve prioridade nos primeiros anos.

Após o registro do descobrimento, seria apenas em 1503 que outro aventureiro viria para explorar. Ele saiu carregado de madeira em seus navios e fundou a primeira feitoria, mas não encontrou metal precioso ou especiaria, o interesse continuava limitado (CALMON, 2002, p. 28). Ainda assim, o governo português e alguns interessados no pau-brasil instalaram feitorias temporárias com sistema de defesa rudimentar a partir desse momento - Igaraçu, Itamaracá, Bahia, Porto Seguro, Cabo Frio, São Vicente. Ainda que fosse um investimento sem boa perspectiva de retorno, a falta de exploração poderia levar à perda daquela região de potencialidades então desconhecidas.

Portanto, o Brasil fora um território praticamente desabitado por portugueses, que circulavam pela costa extraindo pau-brasil e fazendo trocas com os índios - o principal 
controle foi o de dois navios, enviados a partir de 1516, sob liderança de Cristóvão Jacques (CALMON, 2002, p. 33).

A ordem de mudança veio quando Martim Afonso de Souza, um nobre com grande influência política e amigo do monarca, foi incumbido da tarefa de iniciar a exploração do território na América. Ele viria com cinco navios, traçaria a geografia da região, defenderia os interesses portugueses e começaria o povoamento. A descoberta de metais preciosos pelos espanhóis em outras regiões pode ter sido um incentivo para a mudança de planos, mas o interesse de portugueses em iniciar a povoação foi o motivo dado pelo rei em carta a Martim ${ }^{1}$. Martim Afonso de Souza fez uma primeira expedição em 1530 e, enquanto explorava, Dom João III passava a atuar com o objetivo de ocupar o território inexplorado.

Martim chegou em 30 de janeiro de 1531, com quatrocentos homens e cinco navios. Ele portava três cartas régias, que lhe nomeava capitão-mor da armada que vinha ao Brasil ${ }^{2}$, governador das terras que descobrisse e lhe dando poderes para nomear tabeliões, oficiais de justiça e criar e doar sesmarias a pessoas que fizessem parte de sua esquadra (FAORO, 2001, p. 171). Após uma travessia rápida e quase um ano de explorações, Martim Afonso de Souza fundaria São Vicente, o primeiro povoado do Brasil. A partir desse momento se iniciaria a história do Brasil enquanto centro de preocupação dos portugueses.

Um dos fenômenos de maior simbolismo para a história do Direito Público brasileiro ocorre quando Martins Afonso de Souza realiza as primeiras eleições do Brasil e das Américas, em 22 de agosto de 1532. Apesar da inexistência de dados definitivos, as eleições

\footnotetext{
${ }^{1}$ Mensagem de Dom João III em 1532, informando de sua decisão de povoar o Brasil e também que a Martim Afonso de Souza caberia uma capitania com o dobro do tamanho das demais. Traz um trecho: "[...] fui informado que d'algumas partes faziam fundamento de povoar a terra do dito Brasil, considerando eu com quanto trabalho se lançaria fóra a gente que a povoasse, depois de estar assentada na terra, e ter nella feitas algumas forças ' [...] determinei mandar demarca de Pernambuco até o Rio da Prata cincoenta leguas de costa a cada capitania [...]" (Varnhagen, 1839, p. 82).

2 As cartas régias podem ser encontradas no livro publicado por Francisco Adolfo de Varnhagen em 1839, na qual o principal documento é o diário de navegação de Pero Lopes de Souza, mas que traz diversos outros documentos do período. Um trecho da carta de outorga de poderes traz o seguinte: “[...] todas outras pessoas que na dita armada forem e asy a todas as outras pessoas e a quaesquer outras de quaesquer calidade que sejam que nas ditas terras que elle descobrir ficarem e nela estiverem ou a ella forem ter por qualquer maneira que seja que aja ao dito martim afonso de sousa por capitam mor da dita armada e terras e lhe obedecam em todo e por todo o que lhes mandar e cumpram e guardem seus mandados asy e tam jmteyramente como se por mim em pessoa fose mandado sob as penas que elle poser as quaes com efeyto dara a divida execucam nos corpos e fazendas daquelles que ho nom quyserem comprir asy e allem diso lhe dou todo poder alcada mero myster propryo asy no crime como no civel sobre todas as pessoas asy da dita armada como em todalas outras que nas ditas terras que elle descobrir viverem e nella estiverem ou a ella fforem ter por qualquer maneira que seja e elle determjnara sem casos feytos asy crimes como cives e dara neles aquelas sentenças que lhe parecer Justiça conforme a direito e mynhas ordenações ate morte naturall Inclusyue sem de suas sentenças Dar apelacam nem agravo [...]" (Varnhagen, 1839, p. 63).
} 
provavelmente foram feitas sob as normas das Ordenações Manuelinas, que seriam pouco alteradas pelas que a seguiram, as Ordenações Filipinas, e essas seriam utilizadas no Brasil até as eleições municipais de 1828 (FERREIRA, 2001, p. 41).

Não havia nada no Brasil que pudesse ser associado à noção de província ou capitania. A divisão geográfica do poder era rudimentar, um tratado entre potências europeias havia dividido as américas entre suas porções portuguesas e espanholas. O início da ocupação do território pelos europeus seria feito predominantemente por meio de povoamentos organizados autonomamente por escolhidos da coroa. O Brasil iniciou com os povoamentos e, naquele momento, suas câmaras municipais tiveram influência e autonomia (FAORO, 2001, p. 176). Era o resultado da adoção precária das ordenações que vigiam em Portugal, trazidas com a expectativa de lhes aplicar na medida do possível (CAETANO, 1980, p. 9-10).

Apenas um grande contingente de imigrantes poderia permitir que o início da ocupação fosse acompanhado de mais organização e centralização, necessários para aplicar as normas trazidas de Portugal. A ocupação inicial não foi assim, um exemplo disso está na carta enviada em 1532 a Martim Afonso de Souza por Dom João III, que afirma ter deixado no Brasil uma feitoria e apenas sessenta homens com a finalidade de povoar e defender a terra (VARNHAGEN, 1839, p. 82).

\section{CAPITANIAS HEREDITÁRIAS}

\subsection{Surgimento e caracterização}

A organização das capitanias hereditárias denota a importância conferida pelo governo português ao território - grande, mas não tão relevante quanto o comércio com outras regiões. Era uma estratégia refletida para garantir o desenvolvimento de um território que se mostrara maior e mais relevante que uma ilha de pequenas dimensões - como era suposto por Pero Vaz ao descrever pela primeira vez o território encontrado.

O plano das capitanias, do início do século XVI, era mais ambicioso do que o plano de colonização praticado em pequenas ilhas do Atlântico fora (SOUZA JUNIOR, 2002, p. 17). Propostas foram apresentadas e foi adotada a ideia de colonização de Cristóvão Jaques, comandante da armada guarda-costas que defendera o litoral brasileiro contra navios de outras nacionalidades. 
É atribuído a Diogo Gouveia a organização das capitanias, com inspiração nos meios colonizatórios utilizados pelos gregos e fenícios. Ele era um português com alta formação, diretor do Colégio Santa Bárbara em Paris, apoiou o avançado plano exploratório brasileiro e ajudava o governo português desde 1519 (SIMONSEN, 2005, p. 101).

As capitanias foram divididas por lotes de determinado número de léguas contadas verticalmente ao longo da costa - elas tinham entre cento e cinquenta e seiscentos quilômetros. Em relação ao interior, no sentido horizontal, a demarcação seguia até alcançar o Tratado de Tordesilhas. Foram, ao todo, quinze lotes entre 1534 e $1536^{3}$, mas apenas doze capitães. Três lotes foram doados para Pero Lopes de Sousa, que ficou com dois lotes na "costa do ouro e prata" e outro na região produtora de pau-brasil e mais próxima de Portugal Itamaracá.

Os beneficiários eram da baixa nobreza de Portugal. Sete haviam se destacado por sua atuação na África e Índia, quatro eram funcionários da corte e um deles era o capitão de Martim Afonso de Souza. Eram pessoas em cuja capacidade a coroa tinha convicção, mas também pessoas sem grande fortuna ou perspectivas de obtê-la na Europa (CALMON, 2002, p. 35). A falta de recursos do próprio reino também contribuiu para a escolha do sistema, pois um investimento capaz de organizar administrativamente o território não iria ser feito. A esperança era que o investimento privado e a capacidade desses capitães - ou governadores e donatários - fosse o suficiente para alcançar uma colonização bem-sucedida do território ${ }^{4}$.

\subsection{Panorama dos poderes dos capitães}

A tarefa da colonização foi entregue a portugueses sem muitos recursos. Com a finalidade de viabilizar a expedição, foram outorgados grandes poderes e autonomia aos capitães (HESPANHA, 2005, p. 13). A falta de recursos materiais, portanto, não vinha acompanhada da falta de poder (SIMONSEN, 2005, p. 105). Sob esse aspecto, a aproximação com os institutos dos senhores feudais é existente, mas é possível que esses tivessem maior limitação que os capitães. Os senhores feudais estavam em um constante processo de restrição

\footnotetext{
${ }^{3}$ Conforme aponta Simonsen, uma doação inicial fora a Ilha de São João (atual Fernando de Noronha), doado por D. Manuel I em 16 de Fevereiro de 1504. Ela continuou na família que recebera a carta de doação até 1692, mas nunca foi colonizada.

${ }^{4}$ Simonsen nega a ideia de uma forma medieval nessa organização - afirmação presente por muitas décadas nos livros de história do Brasil. A vontade de obter lucro fora o motivo para a vinda dos capitães, e nunca houve classes bem definidas aqui (SIMONSEN, 2005, p. 103).
} 
de seus poderes com o surgimento dos Estados, eram limitados pela Igreja, pelas leis existentes, pelos costumes, pelo seu pacto de vassalagem (CLAVERO, 1986, p. 16-17). Os capitães estavam limitados por vários desses fatores, mas a fiscalização sobre eles era bastante menor. No Brasil, havia poucos meios de aplicar a lei, mas igualmente poucos meios de verificar essa aplicação.

Por certo, a divisão de poderes não existia naquele momento. Diferentes funções estatais já haviam sido descritas até por Aristóteles (1912, Livro VI, Capítulo XI), mas a supremacia do Parlamento só viria quase dois séculos mais tarde, com a Revolução Gloriosa na Inglaterra, em 1688-1689 e a teorização de uma separação (JELLINEK, 2000, p. 534-535) de poderes só seria feita por Montesquieu em 1748 (MONTESQUIEU, 2005, p. 168). Naquele momento, o avanço político se encaminhava apenas para a afirmação da existência de um poder soberano (BODIN, 1583, p. 111) ${ }^{5}$, um processo avançado em Portugal, mas que se manifestava no Brasil de maneira pouco intensa, principalmente por meio do uso das ordenações com normas típicas de um Estado burocratizado e com legislação única.

Não surpreende que as atribuições dos capitães envolvessem todas as funções possíveis e aparecessem na sua plenitude no momento da entrega das capitanias. Para fins de melhoria da compreensão, neste estudo, as funções foram divididas dentro das classificações atuais, legislativo, judiciário, mas não será usado o conceito de executivo, ele será separado em dois para que sejam melhores delineadas as suas funções de então - administração e governo. Será chamado de função de administrar o que envolvia a execução mais direta das leis estabelecidas, excluída a aplicação da lei civil e penal e das organizações dos tribunais (funções do judiciário). E, de função de governo, aquilo que envolvia uma ampla discricionariedade dos capitães para movimentar o poder público em busca dos fins desejados, como na obtenção e no uso de recursos, obras e decisões envolvendo a segurança. Não havia essa noção de separação naquele momento, entretanto, é com o fim de manter a clareza que são adotados esses conceitos.

Seguindo a ordem das próprias cartas, falar-se-á primeiramente na propriedade dos capitães, que contém parte dos dispositivos e prerrogativas. A seguir, serão tratadas as funções de governar, administrar, legislar e julgar.

\footnotetext{
5 "La souveraineté est la puissance absolue et perpétuelle d'une République, [...] c'est-à-dire la plus grande puissance de commander". Tradução livre: "A soberania é o poder absoluto e perpétuo de uma República [...] isto é, o maior poder de comandar".
} 


\subsection{As propriedades dos capitães}

A preocupação do rei nas Cartas de Doação e Foral era a de garantir a viabilidade das capitanias e, como parte desse objetivo, as primeiras disposições da organização delas estão relacionadas à propriedade dos capitães e seus descendentes. Como referido, para a definição básica de todas as seções a seguir, será utilizada a Specimen das Cartas de Doações e Foraes das Capitanias, apresentada por José Izidoro Martins Júnior ${ }^{6}$ (MARTINS JUNIOR, 1895, p. 265 e ss.).

A Capitania Hereditária não era inteiramente transferida à propriedade do capitão, apenas uma fração dela era - cerca de um quinto. O restante deveria ser doado para outras pessoas capazes de utilizar a terra pelo sistema de sesmaria, que será apresentado a seguir. O tamanho da terra a ser de efetiva propriedade do capitão era estabelecido na Carta de Doação, ele escolheria o local, devendo escolher quatro ou cinco porções de terra separadas por pelo menos duas léguas ${ }^{7}$ no prazo de vinte anos. Essa porção de terra não poderia mais sair de sua propriedade, mas ele tinha liberdade para arrendar a terra e cobrar os tributos que desejasse, devendo, em contrapartida, pagar o dízimo "à Deos, á ordem do mestrado de Christo".

Além do direito de propriedade sobre parte da capitania, ele tinha direitos sobre as benfeitorias e sobre os escravos. A respeito das benfeitorias, o capitão tinha direito sobre todas as minas de sal, moendas de água e quaisquer outros engenhos que construíssem na capitania. Nenhuma outra pessoa poderia construir tais benfeitorias sem sua autorização e deveria pagar o quanto lhe conviesse para receber essa licença.

O direito de escravizar fora amplamente outorgado, estabelecendo-se a possiblidade de capturar um número indeterminado de escravos. A limitação era de que o capitão só poderia levar trinta e nove por ano para Lisboa, além daqueles que fossem necessários para preencher a tripulação de seus navios. Nenhum imposto seria pago em função do "resgate" de escravos.

No que tange à sucessão, foi estabelecida a preferência pelo descendente do sexo masculino, legítimo, mais velho, contanto que não fosse de grau mais distante que alguma descendente do sexo feminino, ou "fêmea". Ele herdaria o título de capitão e as propriedades.

\footnotetext{
${ }^{6}$ Foi privilegiado o uso da fonte primária, mas é feito o alerta sobre a possibilidade de variação em relação a outras cartas, pois havia relevante falta de uniformidade no direito português do período (HESPANHA, 2005b, p. 6-7).

${ }^{7}$ A medida légua variou com o tempo, mas sempre esteve entre quatro e sete quilômetros.
} 
$\mathrm{Na}$ falta de descendentes legítimos, herdariam os ascendentes e, após, os colaterais. Inexistindo, herdariam os filhos não legítimos - chamados bastardos pela carta. Qualquer tentativa de desrespeitar essa ordem de sucessão, mesmo que por meio da partilha da propriedade, acarretaria em perda da capitania e imediata sucessão. O capitão era sucedido ainda em vida caso cometesse crime e fosse condenado à perda da capitania - situação que só poderia ocorrer por decisão pessoal do rei.

\subsection{Governo das Capitanias Hereditárias}

As funções de governo do capitão eram reduzidas. A maior parte de suas atribuições era estabelecida nas cartas, cabendo a eles a tarefa de aplicá-las. Apesar disso, podem-se encontrar traços do poder ligado à ideia de governo, de decisão dos assuntos da sociedade, criação de órgãos públicos e sua organização. Nesses aspectos, nota-se em especial a abertura às escolhas do capitão quanto aos ocupantes de cargos, permitindo que uma burocracia fosse formada de acordo com seu desejo, com pouca intervenção da distante coroa.

A primeira das tarefas de governante era a criação de vilas. Cabia-lhe decidir onde criá-las, se perto da costa ou de rios, bem como estabelecer sua jurisdição, liberdades e insígnias segundo os costumes do reino. Caso fossem estabelecidas no interior - sertão -, ele deveria exigir um mínimo de seis léguas de distância uma das outras, ficando o limite excepcional a três léguas de distância. Outra tarefa era a de criar e prover livremente os cargos de tabelião público e judicial. Mas ele não possuía ampla liberdade na criação dos cargos, devendo seguir o provimento régio para suas formalidades. A maior parte dessas tarefas não foi efetivada, poucas foram as vilas fundadas antes de 1548 e da implantação do Governo Geral.

Com os recursos advindos dos tributos, os capitães poderiam realizar as obras que desejassem. As cartas se referem a essa possibilidade expressamente quando atribuem à sua propriedade "as minhas de sal, moendas d'agua, e quaisquer outros engenhos, que se levantarem na capitania" e fala das licenças para a sua construção.

Em caso de guerra, o capitão deveria liderar o corpo armado, formado pelos moradores e povoadores da região, pois eram todos obrigados a servir. Apesar disso, não era direito do capitão declarar guerra ou celebrar a paz, sendo estabelecido apenas o papel de liderança dos corpos armados. 
A ele também pertenciam as alcaidarias-mores das vilas e povoações, com os foros, renda e direitos que tivessem. As pessoas que recebessem esses cargos deveriam "lhe dar homenagem dellas".

Ainda, uma das mais importantes funções governativas dos novos capitães era distribuir a terra para outras pessoas em condições de cultivá-la. Para tanto, foi adotado o sistema de sesmarias ${ }^{8}$, já conhecido em Portugal desde o final do século XIV. Possivelmente, em 1375, foi criada a lei que mais tarde seria reproduzida no título DXXXI, do livro IV das Ordenações Afonsinas e que regrava o funcionamento do instituto. Ele passou a ser utilizado a partir daquele momento, recebendo inúmeros aperfeiçoamentos com a finalidade de ocupar as terras ainda não utilizadas em Portugal, e mais tarde, de garantir reformas agrárias. As terras disponíveis em Portugal acabaram algum tempo depois, mas o instituto e seu funcionamento não era novidade.

Em 1512 já havia uma definição de sesmaria incorporada às Ordenações Manuelinas. "Sesmarias são propriamente as que se dão de terras, casas ou pardieiros que foram ou são de alguns senhorios e que já em outro tempo foram lavadas e aproveitadas e agora o não são". E, mais adiante, "E sendo as terras que forem pedidas de sesmaria mato maninhos ou matas e bravios que nunca foram lavrados e aproveitados ou não há memória de homem que o fossem" (CAETANO, 1980, p. 16).

Não havia o problema de terras abandonadas no Brasil, mas terras que nunca haviam sido lavradas eram abundantes. Por isso foi adotado o sistema de sesmarias, que em resumo propunha que terras fossem distribuídas - por várias gerações - para aqueles que tivessem condições de realmente as utilizar. $\mathrm{O}$ beneficiário tinha o dever de dar uso à terra, sob pena de ver ela retornar ao poder da coroa ou do município a que estivesse vinculada (CAETANO, 1980, p. 17).

A mais detalhada e extensa norma das Cartas de Foral se referia às sesmarias. Nela se normatizava que as terras da capitania deveriam ser dividas em sesmarias e doadas a qualquer pessoa cristã e livre. Sobre essa propriedade, nenhum tributo seria devido além do dízimo.

É estabelecido que o capitão não poderia doar terras que direta ou indiretamente fossem ser propriedade do seu filho varão mais velho, que já herdaria o título de capitão e as

\footnotetext{
${ }^{8}$ O nome, Virginia Rau, citada por Marcello Caetano, sugira da seguinte forma: sesmaria vinha do latim sesmo, que por sua vez derivava de seximus, o sexto. Quando alguma porção de terra de um município deveria ser doada em Portugal, eram nomeados seis repartidores para cuidar delas, chamados sesmeiros. Cada um dos repartidores ficava encarregado de um sesmo durante um dia da semana com exceção do domingo - para não os sobrecarregar. Assim, havia os sesmeiros da segunda-feira, terça-feira e etc. (CAETANO. 1980, p. 17).
} 
suas propriedades. Se alguma sesmaria viesse a pertencer a quem herdou a capitania, ele deveria se desfazer dela em um ano ou perderia a própria sesmaria e outra propriedade de igual tamanho, que passariam a ser propriedade do rei.

As tarefas relacionadas ao governo dos capitães não eram extensas. É notável, também, que boa parte delas tinha aspectos administrativos - após tomada a decisão, os procedimentos para criação de vilas ou de cargos eram os estabelecidos na carta ou nas ordenações. A liberdade de tomada de decisões dos capitães, portanto, é restrita. Havia tomada de decisões políticas desde os primeiros momentos, mas eles eram limitados e previstos com detalhes nas normas portuguesas. A coroa não tomava para si a escolha das pessoas e locais, mas determinava em alguma medida como esses procedimentos seriam feitos.

\subsection{Administração e Tributação das Capitanias Hereditárias}

As mais detalhadas funções dos capitães são as administrativas. Destacam-se, em especial, as normas tributárias, que possuem uma lista detalhada. Todos os tributos do rei e do capitão eram os listados, sendo expressamente proibida a criação de outros tipos, mas ficava à discricionariedade local a cobrança de tributos nas vilas pelos aos alcaides-mores.

As funções administrativas serão agrupadas para a apresentação, pois na carta de Martins Junior, elas aparecem dispersas, por vezes no tratamento de assuntos como propriedade e sucessão. São três os grupos de tributos: tributos para o capitão, tributos para a monarquia e tributos para os alcaides-mores. Tal divisão inexistia nas cartas de foral, mas é importante para garantir uma melhor apresentação das normas.

Os tributos a que o capitão tem direito são oito, eles não tinham nome estabelecido, havia apenas a sua descrição. Será mantida a expressão que estabeleceu o tributo entre aspas, com eventual explicação sobre seu significado.

Primeiro: 5\%, "vintena líquida", do que render o pau-brasil e todas as outras drogas e especiarias aqui encontradas. O pau-brasil deveria ser reservado ao rei, sob pena de confisco de todos os bens do capitão e moradores envolvidos, além de seu degredo perpétuo para ilha de São Tomé. A única exceção era o uso de pau-brasil para fins pessoais, sendo proibida a sua queima. Segundo: 5\%, "meia dizima", de todo o pescado da capitania. Terceiro: 1\%, "redizima ou dizima de todas as dizimas", das rendas e direitos que perceber o rei. Quarto: 
$5 \%$, "e do quinto, se deduzirá o dízimo para o capitão", de todas as pedras preciosas, aljôfares, corais, ouro, prata, cobre e chumbo. Quinto: 1\%, "redizima", do valor dos produtos exportados por navio do Brasil - a exportação para Portugal estava isenta, contanto que em um ano fosse provado o efetivo desembarque. Sexto: 1\%, "redizima" dos valores importados para o Brasil por não portugueses, ainda que os produtos fossem fabricados em Portugal. Sétimo: direito de cobrar pela portagem dos barcos que viessem de rios, precedendo taxação das câmaras e aprovação do rei. E, por fim, oitavo: pensão de quinhentos reis, paga pelos tabeliães público e judicial das vilas e povoações da capitania.

Os tributos devidos ao rei, por sua vez, eram em número de sete. Primeiro: 10\%, “dizima”, dos frutos da terra. Segundo: 5\% "o quinto, [...] do qual se deduzirá a dízima para os capitães", de todas as pedras preciosas, aljôfares, corais, ouro, prata, cobre e chumbo. Terceiro: 10\%, "dizima", de todo o pescado. Quarto: "Siza”, ou sisa, sobre todos os produtos do Brasil vendidos em outras cidades ou partes de Portugal e outros países, ressalvado o direito real ao monopólio do pau-brasil, especiarias e drogas. Quinto: 10\%, "dizima”, do valor dos produtos enviados por navio ao Brasil - a ser pago em Portugal, sem envolvimento do capitão a menos que não fosse feita prova desse pagamento. Sexto: 10\%, "dizima", do valor dos produtos exportados por navio do Brasil - a exportação para Portugal estava isenta, contanto que em um ano fosse provado o efetivo desembarque. Sétimo: 10\%, "dizima" dos valores importados para o Brasil por não portugueses, ainda que os produtos fossem fabricados em Portugal.

Por fim, o último tributo é devido aos alcaides-mores, cargo semelhante ao de um governador de cidade ou vila, nomeado pelo capitão. Esses tributos seriam pagos conforme as ordenações vigentes e elaboradas para os moradores das vilas e povoações. Essas normas sobre os tributos das vilas também mostram como a coroa abria mão de uma normatividade sobre assuntos locais, permitindo o desenvolvimento de normas próprias e aceitas pelos membros da sociedade.

Além dos tributos em si, outras normas tributárias foram estabelecidas. A principal delas é a já citada impossibilidade de criação de novos tributos e diversos casos de não incidências tributárias expressamente estabelecidas pelas cartas. Dentre as previsões de não incidência, a primeira era o direito de importar produtos produzidos para o Brasil - devendo ser feita apenas a prova da dízima paga em Portugal. Um segundo caso de não incidência era 
dos produtos exportados para Portugal e territórios, contanto que comprovado o desembarque em um ano.

Não incidiam também tributos sobre os mantimentos, armamentos e munições de guerra, nacionais ou estrangeiros, que fossem trazidos ao Brasil e aqui negociados com os capitães, moradores e povoadores. Nesse caso, ainda havia a proibição da venda desses produtos aos índios, "gentios" não cristãos, sob pena de perda do dobro do valor das mercadorias. Por fim, era livre de incidência de tributos o comércio entre capitães e moradores de diferentes capitanias.

Além da proibição de negociação de alguns produtos com índios, acima exposta, havia apenas duas normas de natureza administrativa impostas aos capitães. A primeira delas é a de averiguar todas as mercadorias trazidas, devendo o capitão ser avisado do carregamento delas e dar licença para sua partida. Os contraventores deveriam pagar o dobro do valor de todo o carregamento. A segunda é de garantir que todo o vassalo ou morador fosse proibido de negociar com os "Brazis", ainda que fossem cristãos, caso fizesse companhia a algum sujeito de fora de Portugal e seus domínios, sob pena da perda de tudo o que empregasse nesse comércio.

As ordenações portuguesas certamente acresciam outras várias atribuições aos capitães por meio das formalidades existentes para a realização de seus atos. No entanto, pode-se observar uma liberdade ampla de organização das capitanias e uso dos recursos arrecadados com os tributos.

\subsection{Inexistente Função Legislativa das Capitanias Hereditárias}

As Cartas de Doação e Foral não preveem a atribuição de legislar aos capitães. Eles precisariam criar normas específicas para poder governar e administrar, mas o direito de criar normas gerais e abstratas - leis, em sentido amplo - não lhes foi outorgado.

Hespanha explica que a prerrogativa de criar ou revogar normas era um poder extraordinário, visto como oriundo da Graça de Deus, um poder quase divino introduzido na ordem humana. Pela Graça, poderia o rei transformar "quadrados em círculos", conforme disse um jurista português do século XVII. Alterar as leis era um poder do rei, ainda que sempre limitado em eventuais arbitrariedades em função da justiça, equidade, boa-fé, razão e as limitações sociais e políticas existentes (HESPANHA, 2005b, p. 6). Assim, a prerrogativa 
poderia existir na prática, mas não seria outorgada aos capitães - apenas os vice-reis receberiam tal poder no Brasil, muito tempo depois.

\subsection{Jurisdição Civil e Penal das Capitanias Hereditárias}

A principal disposição sobre a jurisdição das capitanias hereditárias é bastante direta. Cabia ao capitão "exercitar toda a jurisdição cível e crime", mas havia limitações de julgamento pelos capitães a diversas pessoas. A passagem ainda normatiza que nas terras da capitania não entraria, em momento algum, corregedor, nem alçada, nem outra estrutura para exercitar a jurisdição de qualquer modo, mesmo que em nome do rei. Essa atribuição é regulada por meio de diversas normas e inclusive relativizada em algumas situações, mas cabia ao capitão ser o juiz, ou nomeá-lo, em quase todas as oportunidades.

No que se refere à administração da jurisdição, cabia ao capitão nomear o ouvidor juiz de mais alta hierarquia, e revisor da decisão dos juízes inferiores em toda a capitania - e seus oficiais, como o meirinho e o escrivão. Caso o crescimento populacional demandasse, a coroa poderia determinar a criação de vários cargos de ouvidores e isso seria providenciado pelo capitão. Pessoalmente ou pelo ouvidor, o capitão deveria também supervisionar a escolha dos juízes - o ocupante do cargo era eleito pela população das vilas e povoados - e fornecer para eles uma carta de confirmação. Essa escolha seria feita pela população local, sem a intervenção da coroa e garantindo que até mesmo os capitães não pudessem impor a cada comunidade quem julgaria seus litígios mais comuns - mais uma vez, demonstrando a abertura da estrutura portuguesa para a cultura local e um domínio muito diferente daquele que um reino com pretensões de absolutismo tentaria impor.

Os juízes eram a hierarquia mais baixa. Eles julgavam em caráter definitivo os casos até a quantia decidida nas ordenações do reino e, após, caberia agravo e apelação ao ouvidor.

Por sua vez, o ouvidor conheceria de todas as ações novas que surgissem a até dez léguas de onde estivesse, bem como apelações e agravos dos casos julgados por juízes acima do valor decidido nas ordenações. O próprio ouvidor, no entanto, estava limitado a julgar casos de até cem mil reis, nos casos de Direito Civil.

No caso de crimes, o ouvidor e o capitão teriam jurisdição conjunta para todas as penas, inclusive a de morte, dos escravos, índios, peões cristãos e homens livres. Não haveria apelação ou agravo dessas decisões. 
Para as pessoas de "môr qualidade", os homens bons, a condenação seria de no máximo dez anos de degredo e cem crusados de multa. Para essas pessoas, a pena de morte poderia ser aplicada em função de quatro crimes: heresia, traição, sodomia e cunhagem de moeda falsa.

Os crimes cometidos pelo capitão seriam julgados pessoalmente pelo rei, que poderia determinar ao capitão que comparecesse a sua presença para ouvi-lo e castigá-lo. Ele não poderia ser suspenso de seu governo e jurisdição em nenhum caso. Se viesse a perder sua capitania, ela passaria ao seu sucessor, sendo que a única exceção seria no crime por traição à coroa.

A última disposição ligada à justiça era a proteção aos criminosos europeus. Para ajudar na colonização e evitar a fuga de portugueses para outros países, muitos condenados poderiam vir para o Brasil como alternativa a outras penas. A chance de não cumprir a pena e vir para ao Brasil se estendia até aos que foram condenados à pena de morte, salvo pelos mesmos crimes de heresia, traição, sodomia e cunhagem de moeda falsa. Vindo ao Brasil, eles não deveriam ser "inquietados" e, passados quatro anos, poderiam ir à Portugal por até seis meses, contanto que não fossem à corte ou ao local onde foi cometido o crime. Essa ida à metrópole poderia se repetir pelo resto de sua vida, a cada quatro anos, pelo mesmo período.

Esse projeto de estrutura judiciária não era compatível com a população existente no Brasil e tampouco havia pessoas com treinamento para ocupar tais cargos. Ele não demonstra uma realidade que estava sendo implantada, bem menos complexa, mas denota a disposição de Portugal para implantar um regime semelhante ao seu e com abertura à autonomia dos habitantes do Brasil.

\section{CONCLUSÃO}

Ainda que sem autonomia para criar leis, os capitães das primeiras capitanias foram dotados de competência extensas, de aplicar a lei e realizar atos de administração e governo. As dificuldades de transporte e comunicação têm um papel nessa descentralização portuguesa, pois dificilmente o rei poderia fiscalizar as restrições que desejasse impor. Mas é aparente, no entanto, a preocupação em deixar aberto o caminho para que fosse grande a liberdade de 
atuação na tentativa de criar um ambiente onde a empreitada dos novos colonizadores pudesse prosperar.

A análise jurídica do Direito Público naquele período permite verificar que o Brasil teve um governo planejado para ser descentralizado e com grande concentração de poder nas mãos daqueles que haviam recebido a confiança do rei para iniciar ocupação do território. Poucas dessas normas poderiam ser efetivadas, e elas faziam parecer que uma sociedade muito complexa já existia aqui, o que não correspondia àquela fase de desenvolvimento.

O sistema de capitanias hereditárias foi modificado em 17 de dezembro de 1548, quando Dom João III institui o Governo Geral do Brasil. Essa centralização de poder instituída naquele momento iria continuar progredindo. $\mathrm{O}$ modelo de capitanias hereditárias descrito acima seria alterado no sentido de atribuir cada vez mais competência e poder fiscalizatório ao governo central. As dificuldades com a agricultura, a hostilidade dos índios, os problemas de transporte e comunicação fizeram com que apenas as capitanias de Pernambuco e São Vicente tivessem alcançado êxito na sua implantação.

\section{REFERÊNCIAS}

ARISTÓTELES. Política. Tradução do grego por William Ellis. Nova Iorque: J M Dent \& Sons LTD., 1912.

BODIN, Jean. Le six livres de la Republique. Paris: Édition Et Présentation De Gérard Mairet, 1583.

CAETANO, Marcello. As Sesmarias no Direito Luso-Brasileiro. In: Estudos de Direito Civil Brasileiro e Português. $1^{a}$ ed. São Paulo: Revista dos Tribunais, 1980.

CALMON, Pedro. História da Civilização Brasileira. Brasília: Senado Federal, 2002.

CLAVERO, Bartolomé. Evolución Historica del Constitucionalismo Español. Madri: Editorial Tecnos S. A., 1986.

DOMINGUES, Francisco Contente. Navios Portugueses dos Séculos XV e XVI. Vila do Conde: Câmara Municipal da Vila do Conde, 2007.

FAORO, Raymundo. Os Donos do Poder. Formação do Patronato Político Brasileiro. $3^{\mathrm{a}}$ ed. São Paulo: Editora Globo, 2001.

FERREIRA, Manoel Rodrigues. A Evolução do Sistema Eleitoral Brasileiro. Brasília: Senado Federal, 2001 
HESPANHA, António Manuel. A Constituição do Império Português. Revisão de Alguns Enviesamentos Correntes. 2005.

HESPANHA, António Manuel. Porque é que existe e em que é que consiste um direito colonial brasileiro. 2005 .

JELLINEK, Georg. Teoría general del Estado. México, FCE, 2000.

MARTINS JUNIOR, José Izidoro. Specimen das Cartas de Doações e Foraes das Capitanias. In História do Direito Nacional. Rio de Janeiro: Typographia da Empreza Democrática Editora, 1895.

MONTESQUIEU, Charles de Secondat, Barão de. O Espírito das Leis. $3^{\text {a }}$ ed., São Paulo: Martins Fontes, 2005.

PEREIRA, Jorge M. As consequências económicas do império: Portugal (1415-1822). Análise Social, Volume XXXII, Número 146-147, 1998, p. 433-461.

PRADO JUNIOR, Caio. Evolução Política do Brasil - Colônia e Império. São Paulo Editora Brasiliense, 2007.

RODRIGUES, Teresa. Portugal nos séculos XVI e XVII. Vicissitudes da dinâmica demográfica. Working Paper do Projecto POCI/DEM/57987/2004 "História da População Portuguesa. Das grandes permanências à conquista da modernidade". Porto: CEPESE, 2014.

SIMONSEN, Roberto C. História Econômica do Brasil 1500-1820. $4^{\mathrm{a}}$ ed. Brasília: Senado Federal, 2005.

SOUZA JÚNIOR, Cezar Saldanha. O Tribunal Constitucional como Poder. Uma Nova Teoria da Divisão dos Poderes. São Paulo: Memória Jardim Editora, 2002.

SOUZA, Pero Lopes de. Diario da navegação da armada que foi á terra do Brasil em 1530 sob a capitania-mor de Martim Affonso de Souza escripto por seu irmão Pero Lopes de Souza; publicado por Francisco Adolfo de Varnhagen. Lisboa: Typographia da Sociedade Propagadora dos Conhecimentos Uteis, 1839. 